\title{
Use of CD25 as an immunohistochemical marker for acquired ocular toxoplasmosis
}

\author{
Uso do CD25 como um marcador imuno-histoquímico de toxoplasmose ocular adquirida
}

\author{
Cristina Miyamoto ${ }^{1,2}$, Rubens Belfort Mattos Neto², Sebastian Di Cesare ${ }^{1}$, Rubens Belfort Junior ${ }^{2}$, Miguel N. Burnier Jr. ${ }^{1,2}$
}

\section{ABSTRACT}

Purpose: Toxoplasmosis is the most common cause of posterior infectious uveitis worldwide. It is often impossible to determine its congenital or acquired nature. Interleukin-2 (IL-2) in peripheral blood has been described as a possible marker for acquired toxoplasmosis. The purpose of this study is to evaluate the histopathological characteristics of ocular toxoplasmosis cases using CD25 as a marker for the expression of interleukin-2.

Methods: Ten formalin-fixed, paraffin-embedded enucleated globes from ten immunocompetent patients with clinical diagnosis of toxoplasmosis were evaluated. Four patients had the acquired form of ocular toxoplasmosis (positive lgM) while six were lgM negative and lgG positive for toxoplasmosis. Histopathological slides were reviewed for the extension of the retinal necrosis, number of toxo cysts, the granulomatous inflammatory reaction, the presence of T and B cells within the choroid and the IL-2 expression. Immunohistochemistry using monoclonal antibodies was performed to observe the expression of CD4, CD8, CD20, CD25, and CD68.

Results: The histopathological evaluation disclosed no differences between acquired and the other ocular toxoplasmosis cases regarding the characteristics studied. However, CD25 showed a higher expression of IL-2 on the 4 acquired cases of ocular toxoplasmosis compared to the remainders.

Conclusions: To the best of our knowledge, this is the first report showing that the use of CD25 as a marker for interleukin-2 could differentiate acquired ocular toxoplasmosis.

Keywords: Toxoplasmosis, ocular/immunology; Immunohistochemistry, Toxoplasmosis, ocular/congenital; Toxoplasmosis, ocular/diagnosis; Interleukon-2/ diagnostic use; Antigens, CD5; Diagnosis, differential; Antigens, differentiation

\section{RESUMO}

Objetivo: Toxoplasmose é a causa mais comum de uveíte posterior no mundo. Em grande parte dos casos, não é possível determinar se a doença ocular é devida a um quadro congênito ou adquirido. Interleucina-2 (IL-2) no sangue periférico foi descrita como um possível marcador de toxoplasmose adquirida. Oobjetivo deste estudo foi avaliar as características de casos de toxoplasmose usando CD25 como um marcador da expressão de interleucina-2.

Métodos: Dez olhos enucleados fixados com formalina e embebidos em parafina de dez pacientes imunocompetentes com diagnóstico clínico de toxoplasmose ocular foram examinados. Quatro pacientes tinham a forma adquirida (IgM positivo) enquanto 6 eram IgM negativo e IgG positivo para toxoplasmose. Cortes histopatológicos foram avaliados quanto a extensão de necrose retiniana, número de cistos de $\mathrm{T}$. gondii, reação granulomatosa e presença de células B e T na coróide, bem como a expressão de interleucina2. Estudo imuno-histoquímico utilizando anticorpos monoclonais foi realizado para determinar a expressão de CD4,CD8, CD20, CD25 e CD68.

Resultados: A avaliação histopatológica não mostrou diferenças entre os casos de toxoplasmose ocular com relação às características avaliadas mencionadas anteriormente. Entretanto, CD25 revelou maior expressão de interleucina-2 nos 4 casos adquiridos comparado com os demais.

Conclusões: Expressão elevada de CD25 foi encontrada em todos os casos de toxoplasmose ocular adquirida. Assim, o uso de CD25 como marcador da interleucina-2 pode ser uma ferramenta útil para diferenciar toxoplasmose ocular congênita de adquirida.

Descritores: Toxoplasmose ocular/imunologia; Imuno-histoquímica; Toxoplasmose ocular/congênito; Toxoplasmose ocular/diagnóstico; Interleucina-2/uso diagnóstico; Antígenos CD5; Diagnóstico diferencial; Antígenos de diferenciação

\section{INTRODUCTION}

$\mathrm{T}$ oxoplasmosis is caused by the intracellular protozoan Toxoplasma gondii ${ }^{(1)}$, that infects up to a third of the world's population (2). Infections may be acquired congenitally or through the ingestion or handling of undercooked or raw infected meat, contaminated vegetables or water ${ }^{(1-3)}$. The disease is asymptomatic in many immunocompetent hosts, however ocular lesions may be present in up to $20 \%$ of infected individuals ${ }^{(1)}$. In immunocompromised patients, the disease often manifests as encephalitis and also ophthalmic lesions ${ }^{(4-6)}$.

Ocular involvement occurs in either congenital or acquired infection. In the United States, infection occurs in 2/1000

Work carried out at the Department of Ophthalmology, Federal University of São Paulo and Mc Gill University, Canada.

Physician, The Henry C. Witelson Ocular Pathology Laboratory, McGill University, Canada. Physician, Departament of Ophthalmology, Universidade Federal de São Paulo - UNIFESP, São Paulo (SP), Brazil.

Correspondence address: Cristina Miyamoto, Departament of Ophthalmology Universidade Federal de São Paulo. Rua Botucatu, 821 - $2^{\circ}$ Andar - São Paulo (SP) - CEP 04023-062 E-mail: crismiyamoto@yahoo.com

Recebido para publicação em 28.04.2010

Última versão recebida em 09.08.2010

Aprovação em 23.10.2010 pregnancies, with a transplacental infection rate $\leq 50 \%(6-7)$. In France, the estimated yearly incidence of contamination in women during pregnancy is 6-7/1000 and of congenital toxoplasmosis is approximately $0.1 \%$ of births ${ }^{(8)}$. Seventy percent of infants with congenital infection show chorioretinal scars ${ }^{(7)}$. Although most of the cases in adults were thought to be a consequence of the reactivation of congenital lesions ${ }^{(9)}$, several studies indicate that ocular disease may be caused by T. gondii infection after birth ${ }^{(1,6,10-12)}$. In fact, most cases in Brazil are a consequence of post-natal infection ${ }^{(6)}$.

Ocular toxoplasmosis is characterized by a necrotizing retinitis with oval or circular lesions ${ }^{(4)}$. It is often impossible to determine the congenital or acquired nature of this particular uveitic process ${ }^{(1-2,13-15)}$. Late onset acquired ocular toxoplasmosis may manifest itself up until at least thirteen years after primary infection ${ }^{(16-17)}$

Interleukin-2 (IL-2) plays an important role in the proliferation and survival of recently activated effector $T$ cells ${ }^{(18)}$. IL-2 in peripheral blood has been described as a possible marker for acquired toxoplasmosis(7). Yamamoto et al. evaluating blood samples from 136 subjects with positive and negative titers of antibody ( $\mathrm{g} M$ and $\operatorname{lgG}$ ) to T. gondii, found that production of IL-2 and interferon-g by peripheral blood mononuclear cells 
from patients with probable congenital toxoplasmosis was decreased, compared to patients with presumed acquired infection $^{(7)}$

CD25 is a transmembrane protein which forms the alpha chain of the IL-2 receptor ${ }^{(19-20)}$. It plays a crucial role in IL-2 homeostasis ${ }^{(20)}$. The goal of this study was to examine the immunohistochemistry expression of CD25 in enucleated eyes of patients with toxoplasmosis, considering the possibility of evaluating histopathologic specimens (Yamamoto et al. studied blood samples by ELISA ${ }^{(7)}$. In addition we aimed to determine whether CD25, as a marker for the expression of IL-2, could differentiate acquired from congenital ocular toxoplasmosis.

\section{METHODS}

Ten formalin-fixed paraffin-embedded enucleated globes from ten immunocompetent patients with clinical diagnosis of toxoplasmosis were evaluated. The globes were obtained from the Henry C. Witelson Ocular Pathology Laboratory. All the subjects had the titers of antibody ( $\mathrm{IgM}$ or $\mathrm{lgG}$ ) to T. gondii determined. Age, gender and number of recurrences was also retrieved.

Histopathological slides were reviewed by one experienced ocular pathologist (MNB) for the extension of the retinal necrosis, number of toxo cysts, the granulomatous inflammatory reaction and the presence of $\mathrm{T}$ and $\mathrm{B}$ cells within the choroid, as well as the IL-2 expression.

Expression of CD4, CD8, CD20, CD25 and CD68 was also evaluated by the avidin-biotin complex (ABC) immunohistochemistry method, using monoclonal antibodies (CD4, CD8, CD 20, CD 25 and CD68) from Dako Laboratory (SPA-830; Stressgen, Victoria, BC, Canada).

The study protocol followed the precepts of the Declaration of Helsinki and was approved by the Research Institute of the McGill University Hospital Centre.

\section{RESULTS}

Clinical information for all ten patients included in the study is summarized in table 1 . Histopathological examination of the enucleated eyes revealed extensive areas of retinal necrosis with accompanying choroidal inflammation (Figure 1). Toxo cysts could be identified within the necrotic retina. Eosinophilic deposits between the retinal pigmented epithelium and the Bruch's membrane could be seen, representing areas of necrosis. However, there were no differences between acquired and IgM negative ocular toxoplasmosis regarding the extension of retinal necrosis and the number of toxo cysts. The granulomatous choroiditis and the presence of $\mathrm{T}$ and $\mathrm{B}$ lymphocytes were also similar in all cases.

Table 1. Clinical data of the patients whose eye globes were enucleated

\begin{tabular}{ccccc}
\hline Case & Sex & Age & Laboratory & Recurrence \\
\hline 1 & M & 37 & $\lg M+$ & 3 \\
2 & F & 61 & $\lg M+$ & 4 \\
3 & F & 58 & $\lg M+$ & 3 \\
4 & M & 63 & $\lg M+$ & 2 \\
5 & M & 72 & $\lg M-$ & 2 \\
6 & F & 56 & $\operatorname{lgM}-$ & 4 \\
7 & F & 43 & $\lg M-$ & 2 \\
8 & F & 47 & $\operatorname{lgM}-$ & 3 \\
9 & M & 56 & $\operatorname{lgM}-$ & 2 \\
10 & F & 74 & $\lg M-$ & 2 \\
\hline
\end{tabular}

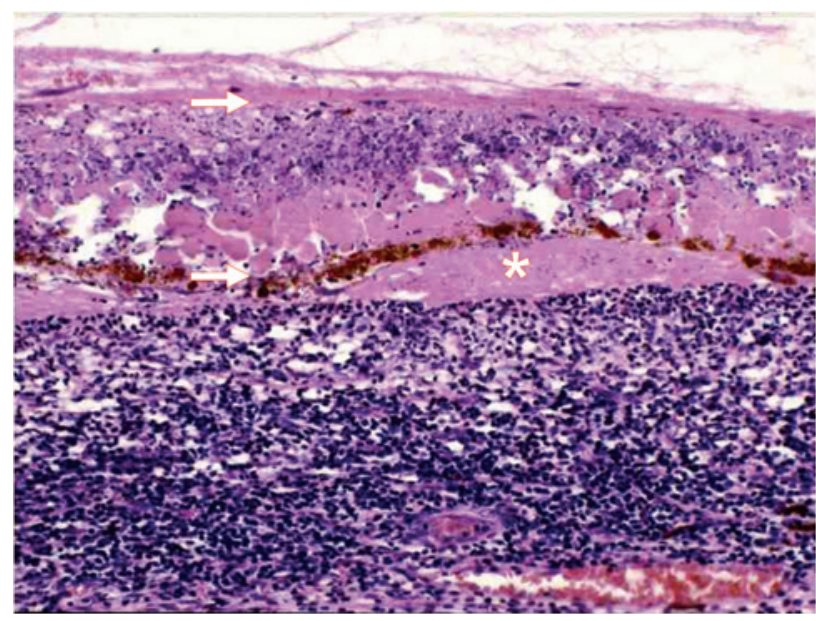

Figure 1. Retinal necrosis containing viable and necrotic toxo cysts (between white arrows). The asterisk shows the sub-RPE eosinophilic deposits corresponding to areas of necrosis. The choroid is infiltrated with lymphocytes and macrophages characterizing a chronic granulomatous inflammation (X 50 magnification).

Regarding immunohistochemical profiling (Graph 1), CD25 was positive (Figure 2) in all (4) IgM positive cases, but only in two out of the six IgM negative patients. No differential expression was seen for CD4 (Figure 3) and CD68.

\section{DISCUSSION}

Infection by T. gondii can be diagnosed indirectly with serological methods or directly by histology, isolation of the parasite or its material (polymerase chain reaction (PCR), hybridization) $)^{(2,6,21)}$.

The diagnosis of ocular toxoplasmosis is mainly clinical(3,22). The presence of anti T. gondii lgG antibodies does not confirm the toxoplasmic etiology, but a negative IgG generally discards the possibility ${ }^{(3)}$. IgG antibodies are detectable for the life of the individual and there is a high prevalence of such antibodies in the general population. On the other hand, IgM antibodies may be detectable for many years in certain patients ${ }^{(22-25)}$

Pathological diagnosis of ocular toxoplasmosis can be established by chorioretinal biopsies or diagnostic enucleation $^{(3,26)}$. The toxoplasma cysts are identified with haematoxylin and eosin, immunohistochemistry using polyclonal or monoclonal antibodies ${ }^{(3,27)}$, or by PCR ${ }^{(17)}$. Histologically, ocular toxoplasmosis often presents extensive granulomatous inflammatory infiltration of the choroid and areas of necrosis under the retinal pigment epithelium ${ }^{(3,26)}$. Furthermore, the parasite's DNA can be identified in vitreous and humour samples using $P C R^{(21,28)}$. Serum levels of chemokines (CXCL8) can also be used, mainly during follow-up (29)

In our study, there were no differences between the cases of ocular toxoplasmosis regarding the extension of retinal necrosis, the number of $T$. gondii cysts, the granulomatous choroiditis and the presence of $T$ and $B$ lymphocytes. However, CD25 showed a differential expression, depending on IgM status. All known cases of acquired toxoplamosis (IgM positive) were positive, while lgM negative cases were mostly negative.

It has been previously reported that patients with a diagnosis of congenital ocular toxoplasmosis secrete significantly less IL-2 in response to soluble toxoplasma tachyzoite antigen (STAg) than do patients with a diagnosis of acquired toxoplasmosis ${ }^{(7)}$. The detection of IL-2 in the serum has been used to 


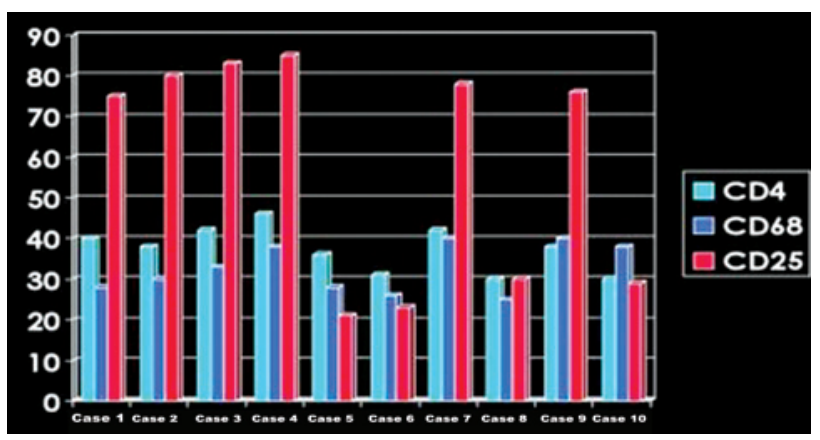

Graph 1. Immunohistochemistry expression of CD4, CD68 and CD25.

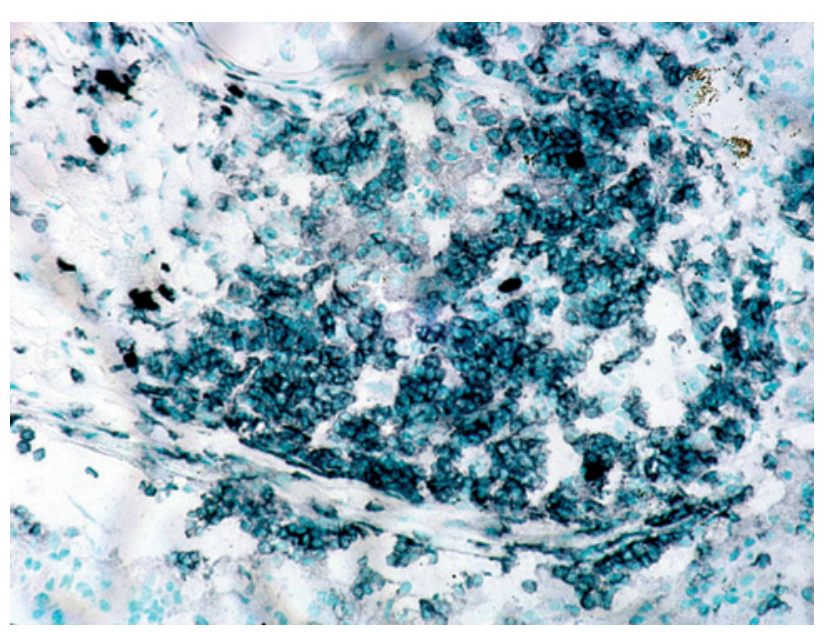

Figure 2. High magnification demonstrating the immunohistochemical expression of CD25 (in green) ( $X 400$ magnification).

distinguish congenital from late acquired cases. Congenital cases are consistently IL-2 negative while acquired toxoplasmosis are positive.

Our study is unique because we had enucleated eyes, so we chose to study the expression of CD25, which is the transmembrane protein of the receptor of IL-2. As expected, all confirmed acquired cases were positive for CD25. It is indeed impossible to determine whether the cases of patients IgM negative were congenital or late acquired ones. Interestingly, we saw that four patients were negative, while two were positive. Considering the previous findings of Yamamoto et al. (7), it is plausible that in this pilot study we were able to distinguish acquired from congenital cases based on CD25 expression. Consequently, further studies comparing confirmed cases of congenital ocular toxoplasmosis to acquired ones are warranted to substantiate our conclusions.

It has been suggested that the mechanisms involved in the development of ocular lesions may be different in the two forms of toxoplasmosis (congenital and acquired), despite the similarity in the pathological characteristics ${ }^{(7)}$. One hypothesis proposes that patients with congenital disease could have been T. gondii-specific T cells deleted or anergized through exposure to toxoplasma antigens during the prenatal period, which could explain the diminished response of T cells from patients with congenital disease $\mathrm{e}^{(7)}$

If the mechanisms of response to ocular toxoplasmosis differs regarding it is congenital or acquired, it would be useful to have specific treatments for each one, in order to obtain a

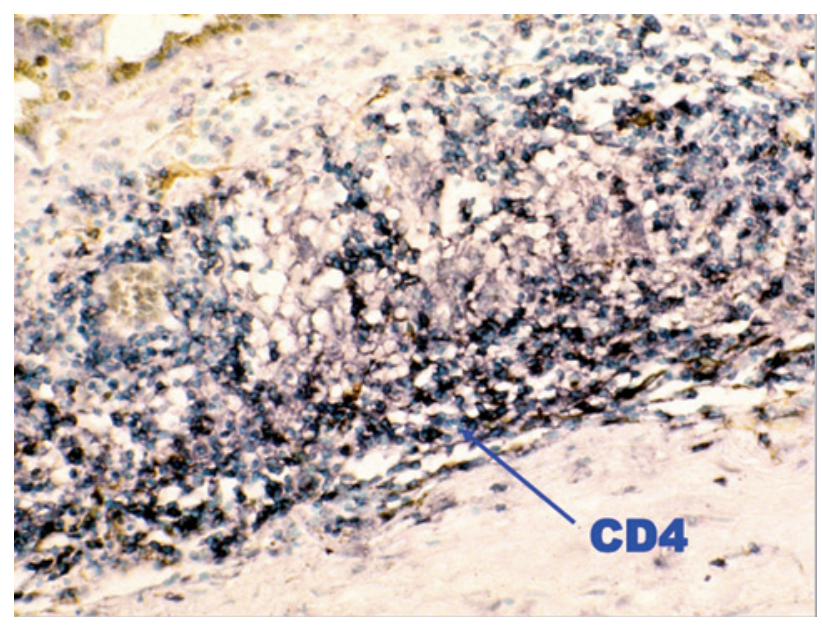

Figure 3. Section of a ocular specimen in a case of toxoplasmosis showing the inflammatory infiltrate and positive immunohistochemical expression of CD4 ( $X$ 400 magnification).

better outcome. Considering that ocular toxoplasmosis is a recurrent disease, especially the congenital form ${ }^{(30)}$, having a method to distinguish both forms can be very useful, helping in treatment and also in the management with different prophylactic measures for recurrent lesions, for instance. Our findings suggest a possible laboratory tool to distinguish them.

\section{CONCLUSIONS}

High expression of CD25 was found exclusively in acquired cases of ocular toxoplasmosis.

To the best of our knowledge, this is the first report showing that the use of CD25 as a marker for IL-2 is helpful to differentiate acquired ocular toxoplasmosis. It further supports the theory that the IL-2 signalling axis may differ between congenital and acquired cases of ocular toxoplasmosis.

Our findings are important because they provide a laboratory tool that could be used to differentiate between acquired and congenital disease, and they may reinforce the hypothesis that the mechanisms involved in the development of ocular lesions may be different in the two forms of disease, despite the similarity in the pathologic features.

\section{REFERENCES}

1. Silveira C, Belfort R Jr, Burnier M Jr, Nussenblatt R. Acquired toxoplasmic infection as the cause of toxoplasmic retinochoroiditis in families. Am J Ophthalmol. 1988; 106(3):362-4.

2. Montoya JG, Liesenfeld O. Toxoplasmosis. Lancet 2004;363(9425):1965-76. Comment in: Lancet. 2004;364(9434):579.

3. Commodaro AG, Belfort RN, Rizzo LV, Muccioli C, Silveira C, Burnier Jr MN, et al. Ocular toxoplasmosis: an update and review of the literature. Mem Inst Oswaldo Cruz. 2009;104(2):345-50.

4. Perkins ES. Ocular toxoplasmosis. Bull Ophthalmol Soc Egypt. 1967:60(64):523-7. 5. Luft BJ, Brooks RG, Conley FK, McCabe RE, Remington JS. Toxoplasmic encephalitis in patients with acquired immune deficiency syndrome. JAMA. 1984;252(7):913-7. 6. Silveira C. Toxoplasmose: levantamento bibliográfico de 1997 a 2000. Arq Bras Oftalmol [Internet]2001 [citado 2010 Set 18];64(3):263-70. Disponivel em: http:// www.scielo.br/pdf/abo/v64n3/12517. pdf

7. Yamamoto JH, Vallochi AL, Silveira C, Filho JK, Nussenblatt RB, Cunha-Neto, E, et al. Discrimination between patients with acquired toxoplasmosis and congenital toxoplasmosis on the basis of the immune response to parasite antigens. J Infect Dis. 2000;181(6):2018-22.

8. Sterkers Y, Varlet-Marie E, Marty P, Bastien P. Diversity and evolution of methods and practices for the molecular diagnosis of congenital toxoplasmosis in France: a four years survey. Clin Microbiol Infect. Forthcoming 2009.

9. Perkins ES. Ocular toxoplasmosis. Br J Ophthalmol. 1973;57(1):1-17. 
10. Saari M Vuorre L, Neiminen $H$ Raisanen S. Acquired toxoplasmic chorioretinitis. Arch Ophthalmol. 1976;94(9):1485-8.

11. Glasner PD, Silveira C, Kruszon-Moran D, Martins MC, Burnier Junior M, Silveira S, etal. An unusually high prevalence of ocular toxoplasmosis in southern Brazil. Am J Ophthalmol. 1992;114(2):136-44

12. Brézin AP, Egwuagu CE, Burnier M Jr, Silveira C, Mahdi RM, Gazzinelli RT, et al. Identification of Toxoplasma gondii in paraffin-embedded sections by the polymerase chain reaction. Am J Ophthalmol. 1990;110(6):599-604.

13. Montoya JG, Rosso F. Diagnosis and management of toxoplasmosis. Clin Perinatol. 2005;32(3):705-26.

14. Montoya JG, Remington JS. Toxoplasmic chorioretinitis in the setting of acute acquired toxoplasmosis. Clin Infect Dis. 1996;23(2):277-82. Comment in: Clin Infect Dis. 1997;24(4):745-6

15. Liesenfeld O, Press C, Montoya JG, Gill R, Isaac-Renton JL, Hedman K, et al. Falsepositive results in immunoglobulin $\mathrm{M}(\mathrm{IgM})$ toxoplasma antibody tests and importance of confirmatory testing: the Platelia Toxo IgM test. J Clin Microbiol. 1997;35(1):174-8.

16. Silveira C, Belfort R Jr, Muccioli C, Abreu MT, Martins MC, Victgora C, et al. A follow-up study of Toxoplasma gondii infection in southern Brazil. Am J Ophthalmol. 2001; 131(3):351-4.

17. Melamed J. Contributions to the history of ocular toxoplasmosis in Southern Brazil. Mem Inst Oswaldo Cruz. 2009:104(2):358-63.

18. Turka LA, Walsh PT. IL-2 signaling and CD4+CD25+ Foxp3+ regulatory T cells. Front Biosci. 2008;13:1440-6.

19. Sakaguchi S, Sakaguchi N, Asano M, Itoh M, Toda M. Immunologic self-tolerance maintained by activated T cells expressing $\|-2$ receptor alpha-chains (CD25). Breakdown of a single mechanism of self-tolerance causes various autoimmune diseases. J Immunol. 1995;155(3):1151-64

20. Létourneau S, van Leeuwen EM, Krieg C, Martin C, Pantaleo G, Sprent J, et al. IL-2/antiL-2 antibody complexes show strong biological activity by avoiding interaction with IL-2 receptor alpha subunit CD25. Proc Natl Acad Sci USA. 2010;107(5): 2171-6.
21. Matos K, Muccioli C, Belfort Junior R, Rizzo LV. Correlation between clinical diagnosis and PCR analysis of serum, aqueous, and vitreous samples in patients with inflammatory eye disease. Arq Bras Oftalmol. 2007;70(1):109-14

22. Rothova A Ocular involvement in toxoplasmosis. Br J Ophthalmol. 1993;77(6):371-7. Erratum in: Br J Ophthalmol. 1993;77(10):683

23. van der Veen J, Polak MF. Prevalence of toxoplasma antibodies according to age with comments on the risk of prenatal infection. J Hyg (Lond). 1980;85(2):165-74.

24. Rothova A van Knapen F, Baarsma GS, Kruit PJ, Loewer-Sieger DH, Kijlstra A. Serology in ocular toxoplasmosis. Br J Ophthalmol. 1986;70(8):615-22

25. Ongkosuwito JV, Bosch-Driessen EH, Kijlstra A, Rothova A. Serologic evaluation of patients with primary and recurrent ocular toxoplasmosis for evidence of recent infection. Am J Ophthalmol 1999:128(4):407-12.

26. Belfort RN, Rasmussen S, Kherani A, Lodha N, Williams G, Fernandes BF, et al. Bilateral progressive necrotizing retinochoroiditis in an immunocompromised patient: histopathological diagnosis. Acta Ophthalmol. 2010;88(5):614-5. Comment in: Acta Ophthalmol. 2010;88(3):e92; author reply e93.

27. Rao NA, Font RL. Toxoplasmic retinochoroiditis: electron-microscopic and immunofluorescence studies of formalin-fixed tissue. Arch Ophthalmol 1977:95(2):273-7.

28. Burg JL, Grover CM, Pouletty P, Boothroyd JC. Direct and sensitive detection of a pathogenic protozoan, Toxoplasma gondii, by polymerase chain reaction. J Clin Microbiol. 1989;27(8):1787-92

29. Goncalves RM, Rodrigues DH, Camargos da Costa AM, Teixeira MM, Ribeiro Campos W. Órefice $C$, et al. Increased serum levels of CXCL8 chemokine in acute toxoplasmic retinochoroiditis. Acta Ophthalmol Scand. 2007;85:(8)871-6.

30. Vasconcelos-Santos DV, Machado Azevedo DO, Campos WR, Oréfice F Queiroz-Andrade GM, Carellos EV, Castro Romanelli RM, Januário JN, Resende LM, Martins-Filho OA, de Aguiar Vasconcelos Carneiro AC, Almeida Vito RW, Caiaffa WT; UFMG Congenital Toxoplasmosis Brazilian Group. Congenital toxoplasmosis in southeastern Brazil: results of early ophthalmologic examination of a large cohort of neonates. Ophthalmology. 2009;116(11): $2199-205$ e1.

\title{
HI Congresso Brasileiro de Catarata \\ e Cirurgia Refrativa
}

\author{
IV Simpósio Brasileiro de \\ Administração em Oftalmologia \\ I Congresso Internacional de \\ Cirurgia Plástica Ocular
}

\author{
01 a 4 de junho de 2011 \\ Porto de Galinhas - PE
}

Informações:

Site: www.catarata-refrativa.com.br/2011 